\title{
Impact of Education Level on Unemployment Rate in Indonesia
}

\author{
Hindun
}

\begin{tabular}{l} 
ARTICLE INFO \\
\hline Article History: \\
Received 15.12.2018 \\
Received in revised form \\
18.02.2019 \\
Accepted \\
Available online 01.07.2019
\end{tabular}

\begin{abstract}
Unemployment is one of the problems that can occur in every region, not even developed countries. This condition can be caused by the incompatibility between work and education and its ability. The analysis used in this study is OLS (Ordinary Least Square) method simple linear regression analysis in 2001-2017. The results of the analysis show that the level of education has a significant and negative influence on the unemployment rate. This shows that the population of secondary school graduates is able to reduce the unemployment rate in Indonesia in 2001 - 2017.
\end{abstract}

(c) IJERE. All rights reserved

Keywords:

Education, High School Graduate, Unemployment.

\section{INTRODUCTION}

Unemployment is one of the problems that can occur in every region, not even developed countries. High unemployment can worsen the economic stability of a country. The problem of unemployment generally occurs in developing countries. One of them is Indonesia. The unemployment rate that occurs in Indonesia is relatively high. This can be seen from the unemployment data according to the World Bank (2018) that the unemployment rate in Indonesia in 2017 was 4.2\%. This data shows that the unemployment rate in Indonesia is still much higher than developed countries such as Japan, which is only $2.8 \%$. This condition can be caused by the incompatibility between work and education and its ability (Rahardja \& Manurung (2008).

Low unemployment rates in developed countries are supported by the quality of their human resources. A developed and large nation is certainly supported by the quality of adequate education for its citizens ( $\mathrm{Wu}, 2018)$. High quality education will enhance the quality of its human resources.

The high and low quality of human resources can be determined from the knowledge and skills they have. Good knowledge and skills are usually obtained from education when they go to school. Each level of school education plays a role in providing learning experiences that can increase student interest (Rina, Murtini \& Indriayu, 2018). One of the levels of school education can be measured from school enrollment rates. Therefore, education has an important role in the life of the nation and state in an effort to create quality human resources (Mahmudah, 2019). Through education, it is expected to reduce all problems faced, especially in reducing unemployment.

So, unemployment is one of the main priorities of society and, in this case, the economic and social structure of each country must make every effort to reduce it (Cristescu, 2017). Therefore, this problem needs to be addressed so as not to cause many problems in a country.

The statement above can be said that to reduce the unemployment rate can be done through the level of education. Danim (2004) suggests that there are three reasons for investment in education. One of them, education can increase income productivity in agriculture and help absorb labor into modern industries. According to Lavrinovicha, Lavrinenko \& Treinovskis (2015), the higher level of education, the more dominant employment status in the labor market. The statement is supported by several studies as follows:

Research Erdem \& Tugcu (2012), higher education graduates are one of the factors that increase the unemployment rate in Turkey in the long run. Although the impact is relatively small, error correction estimates show that higher education also increases the unemployment rate in Turkey in the short term.

The study of Al-Manaseer \& Al-Qudah (2018) found that the output of higher education in Jordan had a positive and significant impact on the unemployment rate in Jordan. Suaidah \& Cahyono (2012) revealed

${ }^{1}$ Corresponding e-mail: albangkalani@gmail.com, orcid.org/0000-0001-7696-1762 University of Surabaya 
that the unemployment rate is influenced by the level of education, especially senior secondary graduates. Sari (2011) states that the level of education has a significant effect on educated unemployment in West Sumatra, meaning that when education levels increase also causes educated unemployment in West Sumatra to increase.

The results of Riddel \& Song's study (2011) show that education significantly increases the level of employment of unemployed people. A very large impact was found in the 12 and 16 school years. Evidence about the impact of formal schools on the incidence of unemployment varies. Horner, Zhang \& Furlong (2018) found that there is a strong negative relationship between higher education spending and unemployment.

Aden (2017), the results of his research show that relatively more educated workers have a comparative advantage in getting a job, because employers retain higher educated workers, and even if they stop or lose their jobs, more educated workers are rehired in more time little compared to workers who are relatively less educated. Therefore, unemployment is generally more prevalent among uneducated or relatively uneducated workers.

Based on the above phenomenon, the researcher wants to examine whether with education, the unemployment rate can be reduced? In other words, can the unemployment rate be influenced by the level of education?

\section{METHOD}

This research is a quantitative study using secondary data. This secondary data is obtained through documentation data collection. The data sources in this study were obtained from the Indonesian Central Bureau of Statistics. The object used is a 17-year time series data in Indonesia from 2001 to 2017.

The data variable used in this study is the unemployment rate by using open unemployment rate data as the dependent variable, and education using education data that is completed by the population at the secondary school level as an independent variable.

The technical analysis used in this study is OLS (Ordinary Least Square) simple linear regression analysis. Simple linear regression analysis tests the effect of one independent variable on one dependent variable (Latan, 2014). Mathematically it can be written as follows:

$$
\mathrm{TPT}=\beta 0+\beta 1 \text { Education }+\varepsilon
$$

Where: TPT is a dependent variable (open unemployment rate), $\beta 0$ is a constant, $\beta 1$ is regression coefficient, education is an independent variable and $\varepsilon$ is an error term.

Using OLS linear regression method, the regression model must meet the classic assumption test. The assumptions are that data must be linear, normal distribution, no multicollinearity, homoscedasticity, and no autocorrelation occurs. Because this research data uses time series data and simple regression, heteroscedasticity and multicollinearity tests do not need to be done. Classical assumption testing can be done by observing the significance values at the level of trust $(\alpha)$ used. The confidence level used in this study was $5 \%(0.05)$.

After answer the classic assumption test, then do the $t$ test and see the coefficient of determination (R2). The $t$ test is used to find out whether the independent variable affects the dependent variable significantly. This research was carried out by observing the significance value of $t$ at the level of $\alpha$ used. If the probability of $\mathrm{t}$-statistic $<5 \%$ means that the independent variable has a significant effect on the dependent variable. R2 ( $\mathrm{R}$ square) is used to determine whether or not the regression model is good. R2 values range from 0 to 1 . The greater R2, the independent variable is closer to the dependent variable, in other words the model is considered good. 
Based on the results of data processing using Eviews, the regression estimation results can be shown as follows.

Table 1 Results of Regression Estimation

\begin{tabular}{lrrrr}
\hline \hline Variable & Coefficient & Std. Error & t-Statistic & Prob. \\
\hline \hline C & 17.34388 & 1.593597 & 10.88348 & 0.0000 \\
Education & -0.336544 & 0.055924 & -6.0179 & 0.0000 \\
\hline \hline R-squared & 0.707118 & & & \\
Adjusted R-squared & 0.687592 & & & \\
\hline \hline
\end{tabular}

Table 1 shows the regression estimation results. From the estimation results obtained a constant value of 17.34388, meaning that if the population who finished high school is constant,the unemployment rate increase by $17.34 \%$. The estimation results also show an educational coefficient of -0.33654 , meaning that if the population who graduated from school rose by $1 \%$, the unemployment rate fell by $0.34 \%$. Based on the estimation results, a simple linear regression model can be written as follows.

$\mathrm{TPT}=17.34388-0.33654$ Education $+\varepsilon$

This study uses the OLS method, because it is necessary to do a classic assumption test. First, the results of the normality test indicate that the probability value of Jarque-Bera (JB) is 0.681319 . These results indicate that the data are normally distributed, it can be seen from the JB probability value greater than the level of confidence that is $0.681319>0.05$. Second, the results of the linearity test show that the F probability value is 0.0777. This result shows that the data is linear, it can be seen from the probability value $\mathrm{F}$ greater than the level of confidence that is $0.0777>0.05$. The last classic assumption test is the autocorrelation test. The autocorrelation test results showed Chi-Square Probability value of 0.0623 . The results show free from autocorrelation problems, as seen from the Chi-Square Probability value greater than the confidence level of $0.0623>0.05$. Based on the results of the classic assumption test, the data shows free from problems.

Table 1 shows the probability value $t$ of 0.0000 . This result shows the probability value $t$ is smaller than $\alpha$, which is $0.0000<0.05$. The value of $\mathrm{R}$ square shows 0.707118 and Adjusted R-squared of 0.687592 . These results indicate that the independent variable is able to explain the effect on the dependent variable at $68.8 \%$.

\section{DISCUSSION}

The results that can be discussed from this study are education variables that can affect unemployment variables. These results are in accordance with what was revealed by Danim that education can help absorb labor into modern industries. In other words, those who are educated will find it easier to find work.

From the results of the research above, the impact of education on unemployment is negative and significant. These results indicate that education is an investment in building a better economy. The higher the education of a person, then the hope will be to get a better job and higher wages. Because of with education, the knowledge and skills that he gets will be more. Those who have better knowledge and skills will find it easier to get a job, either work for someone else, or open their own business, so the unemployment rate can be reduced. In other words, education can reduce the unemployment rate. This research is in line with the findings of Suaidah \& Cahyono (2012), Aden (2017) and Horner, Zhang \& Furlong (2018) that there is a strong negative relationship between higher education expenditures and unemployment, especially senior secondary graduates. Therefore, education can be used as a tool by the government to reduce economic problems, especially the problem of unemployment. To build a better country, the government should continue to improve policies through education to higher education, so the problem of unemployment decreases.

\section{CONCLUSION}


The conclusion that can be conveyed is that the education variable can explain the effect on unemployment by $68.8 \%$, while the rest is influenced by other factors not included in the model, such as wages, government policies, etc. The level of education has a significant and negative influence on the unemployment rate. This means that the higher one's education, the lower the number of unemployed. This shows that the population of secondary graduates is able to reduce the unemployment rate in Indonesia in 2001 - 2017 compared to residents who have graduated from elementary school and even the uneducated population. The higher their education, the better the knowledge and skills they have, so that it is easier to get a job, either work for other people or open a business alone, in the end the unemployment rate can be reduced. Therefore, education can be used as a tool by the government to reduce economic problems, especially the problem of unemployment. To build a better country, the government should continue to improve policies through education to higher education, so the problem of unemployment decreases.

\section{REFERENCES}

Aden, Idilis. (2017). Impact of education on unemployment evidence from Canada. Ottawa: Department of Economics of the University of Ottawa.

Al-Manaseer, D. S. \& Al-Qudah \&Ali, M. (2018) The impact of higher education output on unemployment rates in Jordan. International Journal of Academic Research in Accounting, Finance and Management Sciences 8(2), 65-72.

Central Bureau of Statistics. (2018). Indonesian statistics. Jakarta

Cristescu, A. (2017). The impact of education on the unemployment rate in the southern european model. The Journal of Romanian Regional Science Association, 11(1), 62-75.

Danim, S. (2004). Human resource economics. Bandung: CV. Pustaka Setia.

Erdem, E \& Tugcu, C. T. (2012). Higher education and unemployment: A cointegration and causality analysis of the case of Turkey. European Journal of Education Reseach Development and Policy, 47(2), 299-309.

Horner, S., Zhang, A., \& Furlong, M. (2018). The impact of higher education on unemployment ECON 3161, Fall.

Latan, H. (2014). Application of statistical data analysis for science social sciences with stata. Bandung: Alfabeta.

Lavrinovicha, I., Lavrinenko, O. \& Treinovskis, J. T. (2015). Influence of education on unemployment rate and incomes of residents. Procedia - Social and Behavioral Sciences. 174 (2015), 3824 - 3831.

Mahmudah, R. (2019). The effect of education to Indonesian economic growth. International Journal of Educational Research Review, 4(2), 20-25.

Rahardja, P., \& Manurung, M. (2008). Introduction to economics (microeconomics \& macroeconomics (3rd ed.). Jakarta: Fakultas Ekonomi Universitas Indonesia.

Rina, L., Murtini, W., \& Indriayu, M. (2018). Establishment of entrepreneurial character in the foundation based school system through project based learning. International Journal of Educational Research Review, 3(4), 128-140.

Sari, Anggun Kembar. (2011). Analysis of the influence of education levels, economic growth, and wages on educated unemployment in West Sumatra. Journal of Development Economics, 1-8.

Suaidah, I. \& Cahyono, H. (2012). Effect of education level on unemployment rate in jombang regency. Romanian Journal of Regional Science,11(1), 1-16

$\mathrm{Wu}, \quad \mathrm{S} . \quad$ (2018). The 10 best educational systems in the world. IDN Times. https://www.idntimes.com/life/education/suci-wu-1/

World Bank: World Development Indicators https://www.data.worldbank.org/indicator/SL.UEM.TOTL.ZS 